\title{
Correlation between soil physico-chemical parameters and the diversity of their inhabiting algae
}

\author{
Abd El-Salam M. Shabaan, Hoda A. Mansour *, Neamat H. El Tablawy \\ Botany Department, Faculty of Science, Ain Shams University, Abbassia-11566, \\ Cairo, Egypt
}

\begin{abstract}
Five soil samples (S1-S5) collected from different locations in Egypt to investigate the effect of their physio-chemical parameters on the diversity of algae and their divisions. The results obtained showed that the physio-chemical parameters of the soil have its influence on the diversity of algae. The most varied parameters between the studied locations were soil $\mathrm{pH}$ and the nitrogen contents. The collected algae were 36 species representing 25 genera classified over four divisions. The dominant division was Cyanophyta, which represented by 18 species from 11 genera, followed by Chlorophyta, eleven species belonging to seven genera, then Bacillariophyta and Xanthophyta. The variation in the soil characters between the studied locations affects both the algae richness and diversity. Correlation analyses have been done to investigate the most effective parameters affecting the algae richness and diversity. This study showed that, the soil texture, moisture content, organic matter and nitrogen concentration are the most effective factors in controlling the diversity of soil algae at the studied locations.
\end{abstract}

Keywords: Cyanophytes, Diversity of soil algae, Edaphic algae, Microalgae, Physicochemical of soil.

\section{Introduction}

Algae are diverse group of photosynthetic organisms representing the most abundant primary producers among all living organisms. They are usually inhabitants of aquatic biotopes either freshwater or marine habitats. Algae show a great variety of structure and their sizes range from microalgae to the giant seaweeds. They are widespread in wide range of ecological habitats including air, soil or even extreme habitats such as hot springs, deserts or cold regions (Barsanti and Gualtieri, 2014).

Algae occurs in terrestrial habitats are called edaphic algae where they occur as free living or as resting spores (Metting, 1981). Distribution and diversity of algae in soil are primarily affected by different environmental factors such as degree of exposure to sun light, temperature, water availability and soil properties as well as other biotic factors (Roger and Reynaud, 1982). The 
characterization of different terrestrial algal species is of important matter for exploring their diversity and revealing their biochemical composition. Soil algae have the ability of long survival over long times in the form of resting spores and are adapted to adverse conditions such as xeric habitats (Trainor, 1985;Gupta and Agrawal, 2006; Nayaka et al., 2017).

Most of the studies on algae conducted on aquatic taxa whether freshwater, alkaline or marine species (Shaaban, 1994;El-Sheekh et al., 2010; Khairy and El-Shafay, 2013;Bharathiraja et al., 2015;Dos Santos et al., 2017). The study of the aquatic algae is due to their abundance, easy to observe and propagate in liquid media.

However, purification of mixed soil algal cultures and obtaining of pure and axenic algal strains from the soil is a prerequisite for accurate identification of soil algae and so further any studies of soil algae. In addition, soil contains numerous and diverse potential contaminants such as bacteria, fungi, protozoa, etc., which are difficult to eliminate (Temraleeva et al., 2016).

First publications on cultivation of algae from the soil include those by Bold (1942), Provasoli (1960) and Smith and Wiedeman (1964). For successful cultivation of microalgae different growth factors are needed to be optimized such as light, temperature and nutrient media composition (Andersen, 2005; Singh $\boldsymbol{e t}$ al., 2015). Recently, different techniques are developed for isolation and purification of microalgae especially from soil (Hodac, 2016; Alam et al., 2019; Colsell, 2020).

Nowadays, acceptance of algae as soil microorganisms is more widespread because the fact that algae influence soil structure and the activities of other soil inhabiting organisms (Büdel et al., 2016; van Elsas, 2019). In general, algae have different ecological roles for the soil ecosystem, the most important is that they represent the only primary producers of oxygen in the soil and serve as sources of energy for the soil microorganisms (Schinner et al., 2012). They also provide soil with organic matter and fixed nitrogen which is especially important in reclamation of soil. So that, algae considered as important factor in improving the physical and chemical properties of the soil (Sylvia et al., 2005).

The isolation and identification of soil algae have been studied worldwide including all habitats previously (Blank and Cameron, 1966; Curl and Becker, 
1970; Sullivan and Moncreiff, 1988) and recently (Vijayan and Ray, 2015; Gaysina et al., 2018; Novakovskaya et al., 2020). In Egypt, soil algal flora has been investigated also by different authors. Major studies concerned with algae inhabiting cultivated soils in different regions (El-Ayouty and Ayyad, 1972; Kobbia and Shabana, 1988; Atia, 1993; Ahmed, 1994; Osman, 2003; ElGamal et al., 2008). As well as, some studies were conducted on soil algal flora of the desert habitats (El-Sheekh et al., 1998; Ibraheem, 2003; Mansour and Shaaban, 2010; Shaaban et al., 2017; Mansour et al., 2020).

The present study aims to investigate the relation of soil physico-chemical parameters to the diversity of their inhabiting algae.

\section{Materials and Methods}

\section{Soil sample collection}

According to soils textures, five different types of soil samples collected from uncultivated sites of Egypt, (Table 1 \& 2). Loamy sand soils represented by: sample (1) of MitHelfa (30.149892, 31.235229) and sample (3) of Markaz Belbes $(30.355104,31.446727)$. Meanwhile, sandy soils were represented by: sample (2) of El Obour (30.249269, 31.480298) and sample (4) of El Khankah (30.233523, 31.379677). In addition to the silty loam soil of sample (5) which collected from Basous, El Kanater El Kheireya (30.131975, 31.218565). The subsurface soil layers were removed and freed from gravels and debris. Each of the fine collected soil samples was air dried and stored in sterile clean air-tight plastic bags. Then, each soil sample was divided into two parts; the first part was used for algal cultivation, identification, and isolation and the second part was used to determine the physico-chemical properties.

\section{Soil physico-chemical analysis}

Soil samples were analyzed for determination of different mechanical, physical and chemical parameters at the Desert Research Center in Egypt. First, soil texture (the percentage of sand, silt and clay) were determined by the sedimentation cylinders using the pipette method according to (Page et al., 1982). 
Moisture content of the soil was estimated by oven drying of air-dried known weight of soil sample at $100{ }^{\circ} \mathrm{C}$ for 3 hours. For the soil extracts (1:5), both of electrical conductivity $(\mathrm{mS} / \mathrm{m})$, total dissolved solids $(\mathrm{ppt}), \mathrm{pH}$, soluble cations $\left(\mathrm{Na}^{+}, \mathrm{K}^{+}, \mathrm{Ca}^{2+}, \mathrm{Mg}^{2+}\right)$, anions $\left(\mathrm{Cl}^{-}, \mathrm{SO}_{4}{ }^{2-}, \mathrm{HCO}_{3}{ }^{-}\right)$, available phosphate-P, nitrate-N and micronutrients $(\mathrm{Fe}, \mathrm{Mn}, \mathrm{Cu}, \mathrm{Zn})$ were measured according to Page et al (1982). Soil organic matter was determined using the procedure of Walkely and Black (1934).

Table (1): Soil sampling locations.

\begin{tabular}{clc}
\hline Soil No. & \multicolumn{1}{c}{ Location } & \multicolumn{1}{c}{ GPS } \\
\hline S1 & MitHelfa, Qalyoub & $30.149892,31.235229$ \\
S2 & El Obour & $30.249269,31.480298$ \\
S3 & Markaz Belbes, El Sharqia & $30.355104,31.446727$ \\
S4 & El Khankah & $30.233523,31.379677$ \\
S5 & Basous, El Kanater El Kheireya & $30.131975,31.218565$ \\
\hline
\end{tabular}

\section{Cultivation, isolation and identification of soil algae}

Under aseptic conditions, soil samples were inoculated into liquid autoclaved nutritive media (Chu No.10) in triplicate manner (about $1 \mathrm{~g}$ of soil in a 250 -flask containing $100 \mathrm{ml}$ of media). This medium was specifically selected as it considers the most favorable medium for a variety of algae including green algae, diatoms and cyanobacteria Chu (1942). Then, flasks were incubated in continuous light with a temperature of $24 \pm 1{ }^{\circ} \mathrm{C}$ with continuous shaking until appearance of algal growth.

During the period of propagation, some algal colonies were selected and isolated from the mixture culture again into liquid and solid media to obtain unialgal taxa. Isolation of uni-alga was carried out using the plating and serial dilution method recommended by Jurgensen and Davey (1968). For solid media, about 20 gm of agar-agar were added to one liter of sterilized liquid media, then 
constant volume was poured in Petri-dishes $(9 \mathrm{~cm}$ diameter) and lifted to solidify. Finally, all flasks and plates incubated in the same previous conditions.

Identification of algal taxa were carried out according to Desikachary (1959), De Desenko-Schegolova and Gollerbach (1962), Prescott (1978) and Foged (1980). The microscopically examined algal taxa were photographically recorded using the binocular BEL $®$ photonics biological microscope fitted with a Canon Powershot G12 digital camera.

\section{Statistical analysis}

Data are reported as mean \pm standard deviation from triplicate determination. The physico-chemical analysis of soil samples were compared using one-way ANOVA (SPSS for Windows, version 20) to identify the significant difference between samples $(\mathrm{p}<0.05)$. As well as, the relation between soil physico-chemical variables and algal divisions were evaluated using Pearson's correlation coefficient (r) at $\mathrm{p}<0.05$ and $\mathrm{p}<0.01$ and illustrated with the Biplot of Canonical Correspondence Analysis (Canoco for Windows, version 4.5) (Snedecor and Waddel, 2008).

\section{Results}

\section{Soil analysis and algal diversity}

\subsection{Physico-chemical characteristics of the soil samples}

Five soil samples (S1-S5) were collected from different regions in Egypt (see table 1). Then, the physico-chemical analysis of the studied soil parameters were recorded in table (2). According to mechanical analysis, soil texture varied significantly among samples under investigation from sandy, sandy loam, silty loam to loamy soil. Large percentage of sand particles (90.48 and $88 \%$ respectively) were the major constituents of soil S2andS4 followed with the soil samples of S3andS1 (83 and $79.07 \%$ respectively). Meanwhile, moderate sand percentages were detected in S5 (40\% respectively). In contrast, clay percentages of the soil samples were very low in all studied soil samples. Maximum value of clay was recorded only for S5 (2\%) while lower ratios were detected in S5, S4, $\mathrm{S} 1, \mathrm{~S} 3$ and S2 (2, 1.27, 0.45, 0.33 and $0.15 \%$ respectively) (See fig. 1). 
Table (2): Mechanical, physical and chemical analysis of the studied soil samples (S1: MitHelfa, Qalyoub, S2: El Obour, S3: Markaz Belbes, El Sharqia, S4: El Khankah, S5: Basous, El Kanater El Kheireya).

\begin{tabular}{|c|c|c|c|c|c|}
\hline & S1 & S2 & S3 & S4 & S5 \\
\hline Sand $(\%)$ & $79.07^{\mathrm{d}} \pm 3.55$ & $90.48^{\mathrm{a}} \pm 4.51$ & $83.00^{c} \pm 2.98$ & $88.00^{\mathrm{b}} \pm 3.67$ & $40.00^{f} \pm 1.28$ \\
\hline Silt (\%) & $20.48^{\mathrm{c}} \pm 0.23$ & $9.37^{\mathrm{f}} \pm 0.17$ & $16.67^{\mathrm{d}} \pm 0.54$ & $10.73^{\mathrm{e}} \pm 0.23$ & $58.00^{\mathrm{a}} \pm 1.34$ \\
\hline Clay (\%) & $0.45^{\mathrm{d}} \pm 0.08$ & $0.15^{\mathrm{f}} \pm 0.01$ & $0.33^{\mathrm{e}} \pm 0.07$ & $1.27^{\mathrm{c}} \pm 0.03$ & $2.00^{\mathrm{b}} \pm 0.21$ \\
\hline Texture & Loamy sand & Sand & Loamy sand & Sand & Silty loam \\
\hline pH & $7.86^{\mathrm{c}} \pm 0.14$ & $8.30^{\mathrm{b}} \pm 0.32$ & $8.36^{\mathrm{a}} \pm 0.26$ & $7.06^{\mathrm{e}} \pm 0.15$ & $7.84^{\mathrm{c}} \pm 0.18$ \\
\hline E.C (mS/m) & $15.8^{\mathrm{a}} \pm 0.67$ & $0.56^{c} \pm 0.04$ & $0.24^{\mathrm{e}} \pm 0.01$ & $0.44^{\mathrm{d}} \pm 0.03$ & $0.92^{\mathrm{b}} \pm 0.08$ \\
\hline T.D.S (ppt) & $7.92^{\mathrm{a}} \pm 0.34$ & $0.28^{c} \pm 0.03$ & $0.12^{\mathrm{c}} \pm 0.01$ & $0.22^{\mathrm{c}} \pm 0.02$ & $0.46^{\mathrm{b}} \pm 0.05$ \\
\hline O.M. $(\%)$ & $2.76^{\mathrm{d}} \pm 0.32$ & $0.12^{\mathrm{f}} \pm 0.01$ & $0.87^{\mathrm{e}} \pm 0.04$ & $3.49^{\mathrm{b}} \pm 0.42$ & $4.86^{\mathrm{a}} \pm 0.51$ \\
\hline M.C. (\%) & $18.64^{\mathrm{b}} \pm 0.77$ & $0.23^{\mathrm{f}} \pm 0.02$ & $7.46^{\mathrm{d}} \pm 0.61$ & $12.13^{\mathrm{c}} \pm 0.29$ & $23.12^{\mathrm{a}} \pm 0.82$ \\
\hline $\mathbf{N a}^{+}$ & $2713.25^{\mathrm{a}} \pm 6.50$ & $60.23^{\mathrm{b}} \pm 0.98$ & $13.10^{\mathrm{e}} \pm 0.14$ & $44.60^{c} \pm 0.43$ & $57.48^{\mathrm{b}} \pm 0.23$ \\
\hline $\mathbf{K}^{+}$ & $69.21^{\mathrm{a}} \pm 0.71$ & $2.35^{\mathrm{f}} \pm 0.13$ & $3.13^{\mathrm{e}} \pm 0.32$ & $16.03^{\mathrm{c}} \pm 0.33$ & $17.99^{\mathrm{b}} \pm 0.45$ \\
\hline $\mathbf{C a}^{++}$ & $872.54^{\mathrm{a}} \pm 4.10$ & $41.68^{\mathrm{d}} \pm 1.26$ & $30.06^{f} \pm 1.73$ & $107.82^{\mathrm{b}} \pm 3.22$ & $104.41^{\mathrm{c}} \pm 2.82$ \\
\hline $\mathbf{M g}^{++}$ & $440.13^{\mathrm{a}} \pm 3.97$ & $10.09^{c} \pm 0.35$ & $3.04^{\mathrm{d}} \pm 0.29$ & $11.91^{\mathrm{c}} \pm 0.42$ & $12.52^{\mathrm{c}} \pm 0.57$ \\
\hline $\mathrm{Cl}^{-}$ & $4837.86^{a} \pm 8.10$ & $73.74^{e} \pm 0.75$ & $58.14^{\mathrm{f}} \pm 2.70$ & $128.33^{b} \pm 3.78$ & $112.73^{c} \pm 3.48$ \\
\hline $\mathrm{SO}_{4}^{--}$ & $2809.76^{a} \pm 5.82$ & $42.75^{\mathrm{d}} \pm 1.70$ & $33.62^{\mathrm{e}} \pm 1.18$ & $163.30^{c} \pm 3.89$ & $238.23^{\mathrm{b}} \pm 4.90$ \\
\hline $\mathrm{HCO}_{3}{ }^{-}$ & $282.52^{\mathrm{a}} \pm 4.32$ & $161.09^{b} \pm 3.93$ & $3.66^{\mathrm{f}} \pm 0.28$ & $102.51^{\mathrm{d}} \pm 3.50$ & $65.29^{\mathrm{e}} \pm 0.59$ \\
\hline $\mathbf{N}$ & $44^{\mathrm{d}} \pm 0.19$ & $26^{\mathrm{f}} \pm 0.09$ & $55^{\mathrm{b}} \pm 0.44$ & $42^{\mathrm{e}} \pm 0.10$ & $52^{c} \pm 0.34$ \\
\hline $\mathbf{P}$ & $12.2^{c} \pm 0.22$ & $2.3^{\mathrm{e}} \pm 0.08$ & $8.2^{\mathrm{d}} \pm 0.12$ & $24.2^{\mathrm{a}} \pm 0.20$ & $1.38^{\mathrm{f}} \pm 0.07$ \\
\hline $\mathbf{F e}$ & $28^{c} \pm 0.33$ & $19^{\mathrm{d}} \pm 0.17$ & $18^{\mathrm{e}} \pm 0.19$ & $32^{\mathrm{b}} \pm 0.26$ & $36^{\mathrm{a}} \pm 0.41$ \\
\hline Mn & $22^{c} \pm 0.30$ & $11^{\mathrm{e}} \pm 0.13$ & $14^{\mathrm{d}} \pm 0.15$ & $24^{b} \pm 0.23$ & $28^{\mathrm{a}} \pm 0.40$ \\
\hline $\mathbf{Z n}$ & $18^{\mathrm{a}} \pm 0.16$ & $8^{\mathrm{e}} \pm 0.09$ & $10^{\mathrm{d}} \pm 0.18$ & $14^{\mathrm{c}} \pm 0.27$ & $16^{\mathrm{b}} \pm 0.28$ \\
\hline $\mathbf{C u}$ & $10^{\mathrm{b}} \pm 0.99$ & $4^{e} \pm 0.04$ & $6^{\mathrm{d}} \pm 0.07$ & $10^{\mathrm{b}} \pm 0.10$ & $9^{c} \pm 0.09$ \\
\hline
\end{tabular}

*Values are expressed as average \pm standard error. Different letters indicate a significant difference at the level of $\mathrm{p} \leq 0.05$. 
On the other hand, $\mathrm{pH}$ values showed non-significant variations in the investigated soil samples where it was slightly to moderately alkaline (7.06 to 8.36). In relevant to organic matter and moisture contents, there was a significant positive relation between them (See fig. 1). Higher value of organic matter was observed in S5 (4.86\%) location followed by nearable values of S4, and S1 (3.49 and $2.76 \%$ respectively) whereas, minimum value $(0.87$ and $0.12 \%)$ were recorded in both S3 and S2. In the same manner, moisture content was the highest in S5 (23.12\%) followed by soil samples of S1, S4 and S3 (18.64, 12.13 and 7.46 $\%$ respectively) and lowest percentage was recorded only for S2 soil sample ( 0.23 $\%)$.

Regarding to the chemical analysis of soil samples, values of cations $\left(\mathrm{Na}^{+}, \mathrm{K}^{+}, \mathrm{Ca}^{2+}\right.$ and $\left.\mathrm{Mg}^{2+}\right)(2713.25,69.21,872.54$ and $440.13 \mathrm{ppm}$ respectively) and anions $\left(\mathrm{Cl}^{-}, \mathrm{SO}_{4}{ }^{2-}\right.$ and $\left.\mathrm{HCO}_{3}{ }^{-}\right)(4837.86,2809.76$ and $282.52 \mathrm{ppm}$ respectively) were the maximum in soil of S1 among all locations. Moreover, data of fig (1) showed maximum records for EC and TDS values $(15.84 \mathrm{mS} / \mathrm{m}$ and $7.92 \mathrm{ppt}$ respectively). However, lower contents of the same ions were recorded in $\mathrm{S} 3$; cations (13.10, 3.13, 30.06, $3.04 \mathrm{ppm}$ respectively) and anions (58.14, 33.62 and $3.66 \mathrm{ppm}$ respectively). So that, lower EC and TDS values also were recognized $(0.24 \mathrm{mS} / \mathrm{m}$ and $0.12 \mathrm{ppt}$ respectively). In addition to, relatively higher concentrations of $\mathrm{Ca}^{2+}, \mathrm{Cl}^{-}$and $\mathrm{SO}_{4}{ }^{2-}$ were recorded in the soil samples of $\mathrm{S} 4$ (107.82, 128.33 and 163.30 ppm respectively) and S5 (104.41, 112.73 and 238.23 ppm respectively). Also, $\mathrm{HCO}_{3}{ }^{-}$values were higher in $\mathrm{S} 2, \mathrm{~S} 6$ and $\mathrm{S} 4$ locations (161.09, 118.38 and $102.51 \mathrm{ppm}$ respectively). While other locations showed nonsignificant differences in the previous parameters (See table 2).

Moreover, location S2 has minimum values of nitrogen whereas for phosphorous lower values were found in $\mathrm{S} 5(1.38 \mathrm{ppm})$. On the other side, maximum value for nitrogen was recorded in S3 and S5 (55 and $52 \mathrm{ppm}$ ) whereas other localities recorded nearable values (See Fig. 1) as well as maximum value of phosphorous was detected in S4 (24.2 ppm). Additionally, lower micronutrients contents $(\mathrm{Mn}, \mathrm{Fe}, \mathrm{Zn}$ and $\mathrm{Cu})$ were also observed in Soil No.2 $(19,11,8$ and 4 ppm respectively). 


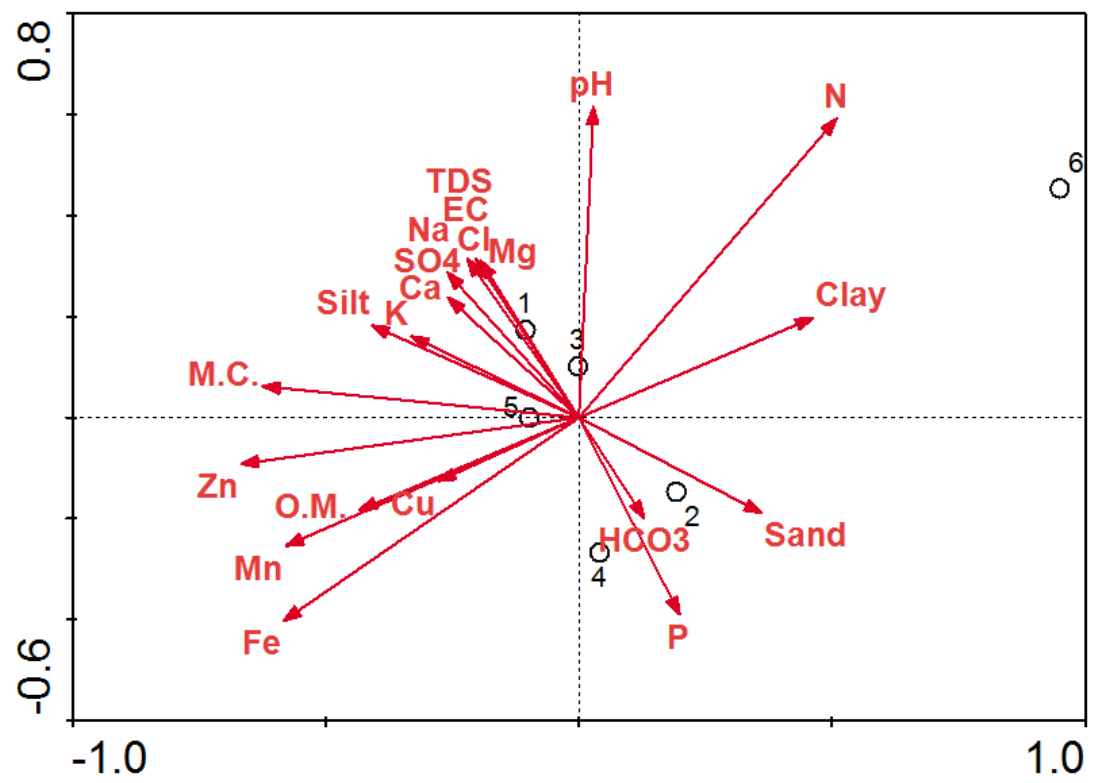

Figure (1): Biplot of Canonical Correspondence Analysis showing the relationships between the different localities under investigation and physico-chemical parameters of the soil.

\subsection{Algal diversity of the collected soil samples}

Data in table (3) revealed the presence of total 36 algal taxa (25 genera) in the algal mixtures of all soil samples belonging to four algal divisions. These were dominated with Cyanophyta about 18 blue green algal taxa (11 genera) followed by Chlorophyta 11 green algal taxa (7 genera), while Bacillariophyta (Diatoms) and Xanthophyta (Yellow-green) were represented only by 4 and 3 algal taxa respectively. 
Table (3): Total number of algal taxa (genera) recorded per each algal division within the different locations understudy.

\begin{tabular}{lccccc}
\hline \multicolumn{1}{c}{ Algal divisions } & S1 & S2 & S3 & S4 & S5 \\
\hline Cyanophyta & 1 & 2 & $10(6)$ & 3 & $8(6)$ \\
Chlorophyta & 2 & 2 & $4(3)$ & 2 & $8(5)$ \\
Xanthophyta & - & 2 & 2 & 1 & - \\
Bacillariophyta & 1 & - & 4 & - & 3 \\
Total & $\mathbf{4}$ & $\mathbf{6}$ & $\mathbf{2 0}(\mathbf{1 5})$ & $\mathbf{6}$ & $\mathbf{1 9}(\mathbf{1 4})$ \\
\hline
\end{tabular}

Among the highly recorded blue-green algal taxa were Stratonostoc linckia (Roth) Elenk and Anabaena constricta (Szaf.) Geitl. On the other side, the most dominant species of Chlorophyta among different locations were Chlamydomonas globosa Snow and Scenedesmus bijugatus var. graevenitzii (Bernard) comb. nov. Concerning Xanthophyta, only three taxa were revealed namely Chloridella simplex Pasch., Pleurochloris pyrenoidosa Pasch. and Botrydiopsis eriensis Snow. Meanwhile, rarely frequency of Bacillariophyta was recorded at all soil samples (Table 4).

Regarding the number of recorded algal taxa within each site (Table 3), the soil No (3) was found to be the richest one (20 taxa) and S5 (19 taxa) followed by S4 and S2 (6 taxa each one). However, the least number of taxa was noted in $\mathrm{S} 1$ (4 taxa). It was shown also that, the largest number of blue-green algae was recorded in S3 followed by S5 (10 and 8 algal taxa respectively), while the lowest number was found at S4, S2 and S1 (3,2 and 1 algal taxa respectively). In addition, S5 showed rich flora of Chlorophyta followed by S3 (8, 4 algal taxa respectively), meanwhile other locations were poor in Chlorophyta. Concerning Xanthophyta, only 3 algal taxa were found at S2, S3 and S4. However, Bacillariophyta were represented only in the soils of S1, S3 and S5. 
Table (4): Recorded soil algal flora of the locations under investigation.

\begin{tabular}{|c|c|c|c|c|c|c|c|}
\hline & Plate & Fig. & S1 & $\mathbf{S 2}$ & S3 & $\mathbf{S 4}$ & $\mathbf{S 5}$ \\
\hline \multicolumn{8}{|l|}{ Cyanophyta } \\
\hline Aphanothece microscopica Näg. & 1 & A & - & - & - & - & + \\
\hline Merismopedia punctate Meyen & 1 & B & - & - & - & - & + \\
\hline Gloeocapsa minor (Kütz.) Hollerb. & 1 & $\mathrm{C}$ & - & - & - & - & + \\
\hline Gloeocapsa minuta (Kütz.) Hollerb. & 1 & $\mathrm{D}$ & - & - & - & - & + \\
\hline Gloeocapsa turgida (Kütz.) Hollerb. & 1 & $\mathrm{E}$ & - & - & - & - & + \\
\hline Myxosarcina chroococcoides & 1 & $\mathrm{~F}$ & - & + & - & - & - \\
\hline $\begin{array}{l}\text { Amorphonostoc paludosum (Kütz.) } \\
\text { Elenk }\end{array}$ & 1 & G & - & - & + & - & - \\
\hline $\begin{array}{l}\text { Amorphonostoc punctiform f. } \\
\text { populorum(Kütz.) Elenk. }\end{array}$ & 1 & $\mathrm{H}$ & - & - & + & + & - \\
\hline $\begin{array}{l}\text { Stratonostoc linckia f. linckia (Roth) } \\
\text { Elenk. }\end{array}$ & 1 & I & - & + & + & - & + \\
\hline $\begin{array}{l}\text { Stratonostoc linckia f. calcicola } \\
\text { (Bréb.) Elenk }\end{array}$ & 1 & $\mathbf{J}$ & - & - & - & + & - \\
\hline $\begin{array}{l}\text { Sphaeronostoc corulum (Lyngb.) } \\
\text { Elenk }\end{array}$ & 1 & $\mathrm{~K}$ & - & - & + & - & - \\
\hline $\begin{array}{l}\text { Sphaeronostoc microscopicum } \\
\text { (Carm.) Elenk }\end{array}$ & 1 & $\mathrm{~L}$ & - & - & + & - & - \\
\hline Anabaena constricta (Szaf.) Geitl & 2 & A & + & - & + & - & + \\
\hline Anabaena contorta Bachm & 2 & B & - & - & - & + & - \\
\hline Anabaena oscillarioides Bory & 2 & $\mathrm{C}$ & - & - & + & - & - \\
\hline $\begin{array}{l}\text { Nodularia harveyana f. } \\
\text { sphaerocarpa (Born. et. Flah.) } \\
\text { Elenk }\end{array}$ & 2 & $\mathrm{D}$ & - & - & - & + & - \\
\hline Calothrix brevissima G. S. West & 2 & $\mathrm{E}$ & - & - & + & - & - \\
\hline Oscillatoria jasorvensis Vouk & 2 & $\mathrm{~F}$ & - & - & + & - & - \\
\hline Oscillatoria princeps Vaucher & 2 & G & - & - & + & - & + \\
\hline Total & & & & & 18 & & \\
\hline \multicolumn{8}{|l|}{ Chlorophyta } \\
\hline Chlamydomonas globosa Snow & 3 & A & - & + & + & + & - \\
\hline $\begin{array}{l}\text { Tetraedron minimum (A. Braun) } \\
\text { Hansg. }\end{array}$ & 3 & B & + & - & - & - & - \\
\hline $\begin{array}{l}\text { Chlorococcum humicola (Naegeli) } \\
\text { Rabenhorst }\end{array}$ & 3 & $\mathrm{C}$ & - & - & - & - & + \\
\hline Chlorella vulgaris Beijerinck & 3 & $\mathrm{D}$ & - & - & + & - & + \\
\hline
\end{tabular}




\begin{tabular}{|c|c|c|c|c|c|c|c|}
\hline Scenedesmus bijugatus Kütz & 3 & $E$ & - & + & + & + & - \\
\hline $\begin{array}{l}\text { Scenedesmus bijugatus var. } \\
\text { graevenitzii (Bernard) comb. nov. }\end{array}$ & 3 & $\mathrm{~F}$ & - & - & - & - & + \\
\hline $\begin{array}{l}\text { Scenedesmus obliquus (Turpin) } \\
\text { Kütz }\end{array}$ & 3 & G & + & - & + & - & + \\
\hline $\begin{array}{l}\text { Scenedesmus quadricauda (Turpin) } \\
\text { Brébisson }\end{array}$ & 3 & $\mathrm{H}$ & - & - & - & - & + \\
\hline $\begin{array}{l}\text { Pediastrum simplex var. } \\
\text { duodenarium (Bailey) Rabenh }\end{array}$ & 3 & I & - & - & - & - & + \\
\hline $\begin{array}{l}\text { Pediastrum duplex var. reticulatum } \\
\text { (Meyen) Lagerheim }\end{array}$ & 3 & $\mathbf{J}$ & - & - & - & - & + \\
\hline Coelastrum microporum Nägeli & 3 & $\mathrm{~K}$ & - & - & - & - & + \\
\hline Total & & & & & & & \\
\hline \multicolumn{8}{|l|}{ Xanthophyta } \\
\hline Chloridella simplex Pasch. & 3 & $\mathrm{~L}$ & - & + & + & - & - \\
\hline Pleurochloris pyrenoidosa Pasch. & 3 & M & - & + & - & - & - \\
\hline Botrydiopsis eriensis Snow & 3 & $\mathrm{~N}$ & - & - & + & + & - \\
\hline Total & & & \multicolumn{5}{|c|}{3} \\
\hline \multicolumn{8}{|l|}{ Bacillariophyta } \\
\hline Cyclotella & & & - & - & + & - & + \\
\hline Achnanthus & & & + & - & + & - & - \\
\hline Nitzschia & & & - & - & + & - & + \\
\hline Synedra & & & - & - & + & - & + \\
\hline Total & & & \multicolumn{5}{|c|}{4} \\
\hline
\end{tabular}



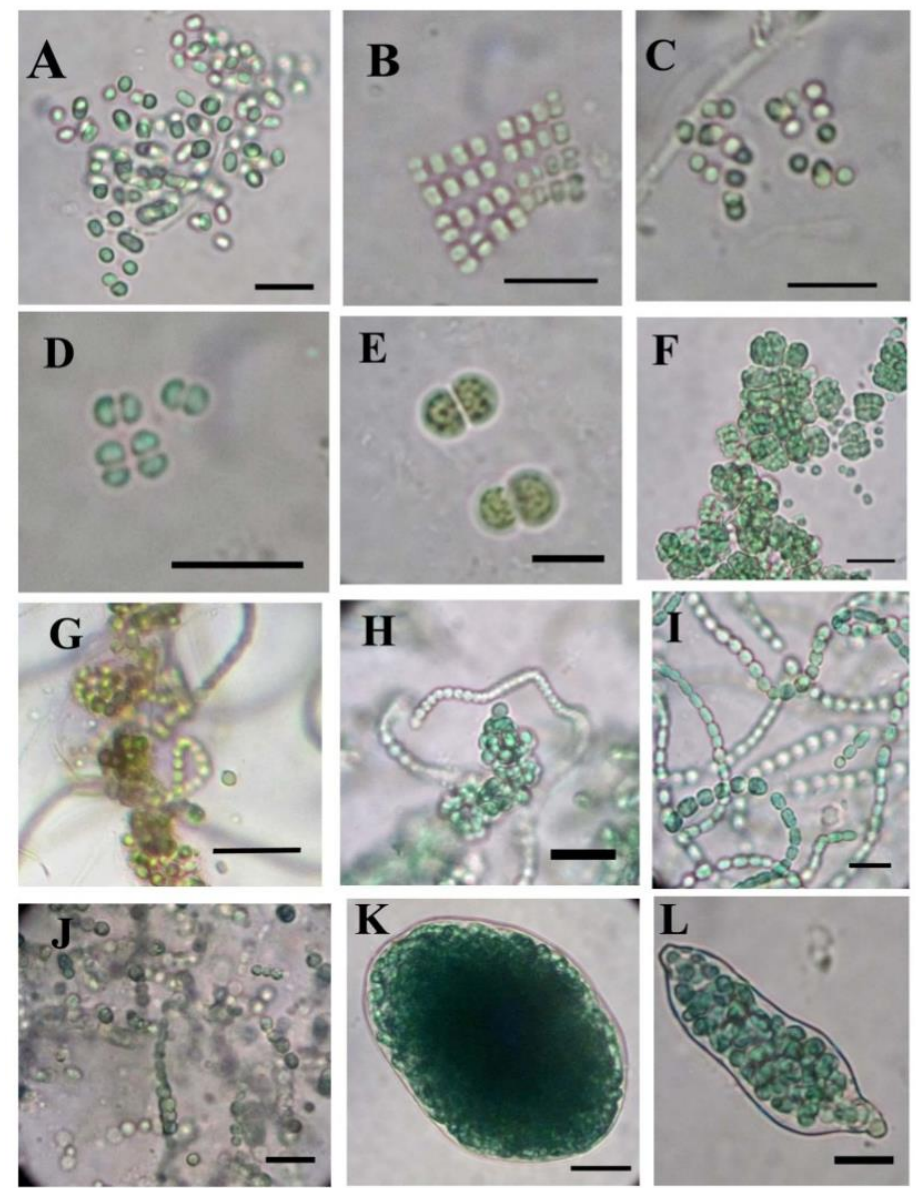

*Scale bar $=10 \mu \mathrm{m}$.

Plate 1 (A-L): Figs. A) Aphanothece microscopica Näg. B) Merismopedia punctate Meyen, C) Gloeocapsa minor (Kütz.) Hollerb. D) Gloeocapsa minuta (Kütz.) Hollerb. E) Gloeocapsa turgida (Kütz.) Hollerb. F) Myxosarcina chroococcoides Geitler. G) Amorphonostoc paludosum (Kütz.) Elenk. H) Amorphonostoc punctiform f. populorum (Kütz.) Elenk. I) Stratonostoc linckia f. linckia (Roth) Elenk. J) Stratonostoc linckia f. calcicola (Bréb.) Elenk, K) Sphaeronostoc corulum (Lyngb.) Elenk, L) Sphaeronostoc microscopicum (Carm.) Elenk. 

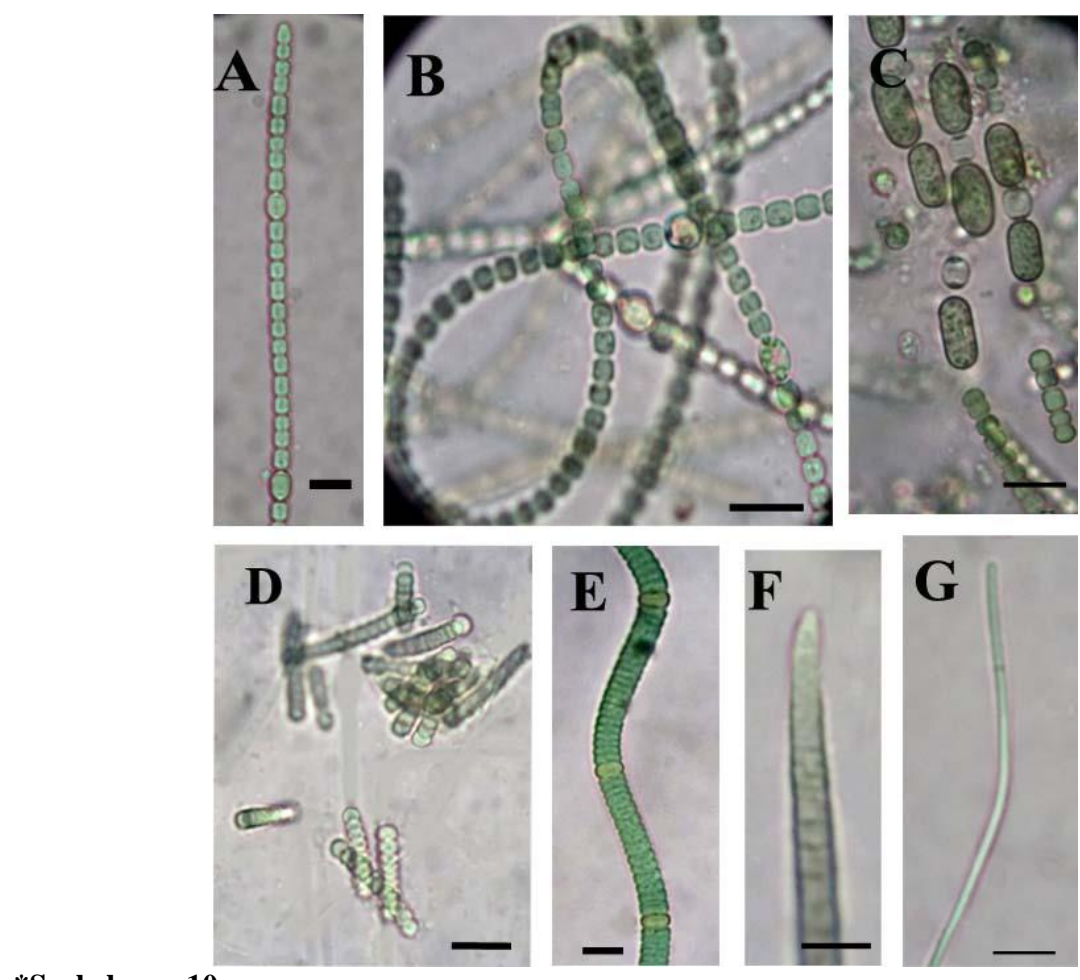

*Scale bar $=\mathbf{1 0} \mu \mathrm{m}$.

Plate 2 (A-G) Figs. A) Anabaena constricta (Szaf.) Geitl. B) Anabaena contorta Bachm. C) Anabaena oscillarioides Bory. D) Nodularia harveyana f. sphaerocarpa (Born. et. Flah.) Elenk. E) Calothrix brevissima G. S. West. F) Oscillatoria jasorvensis Vouk. G) Oscillatoria princeps Vaucher. 

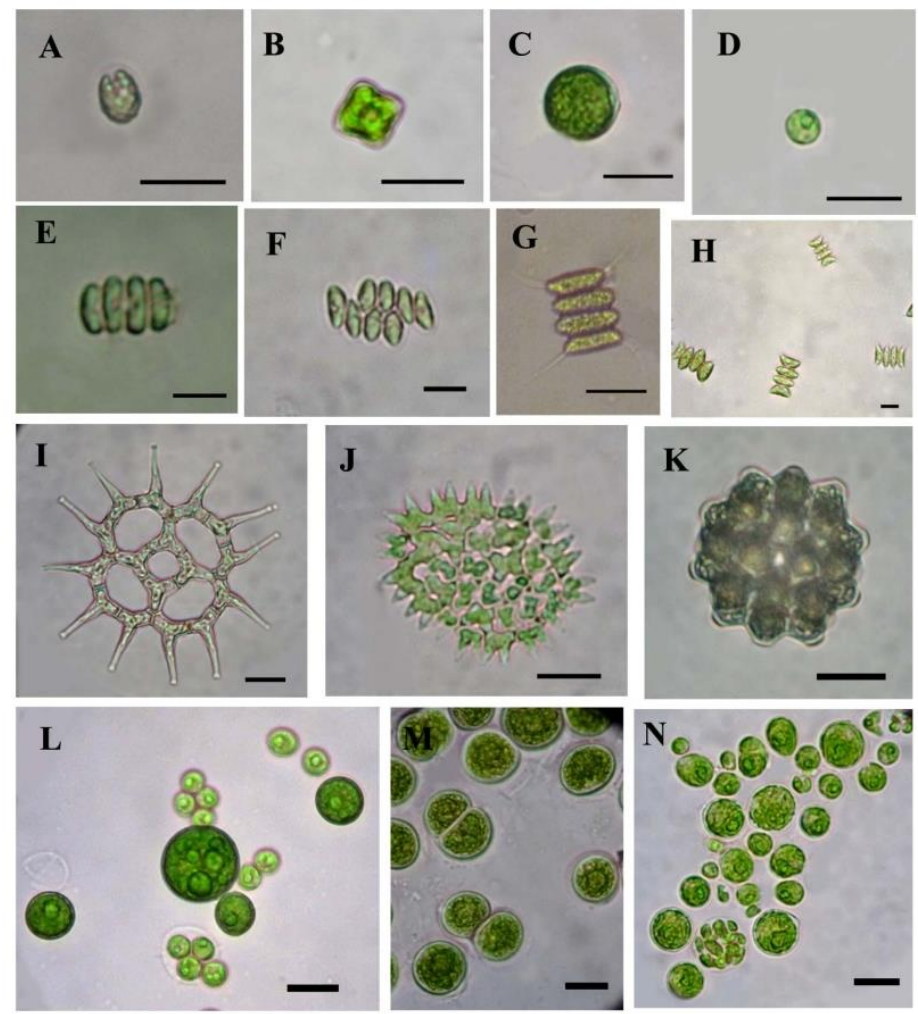

*Scale bar $=10 \mu \mathrm{m}$.

Plate 3 (A-N): Figs. A) Chlamydomonas globosa Snow. B) Tetraedron minimum (A. Braun) Hansg. C) Chlorococcum humicola (Nageli) Rabenhorst. D) Chlorella vulgaris Beijerinck. E) Scenedesmus bijugatus Kütz. F) Scenedesmus bijugatus var. graevenitzii (Bernard) comb. nov. G) Scenedesmus obliquus (Turpin) Kütz. H) Scenedesmus quadricauda (Turpin) Brébisson. I) Pediastrum simplex var. duodenarium (Bailey) Rabenh. J) Pediastrum duplex var. reticulatum (Meyen) Lagerheim. k) Coelastrum microporum Nägeli. L) Chloridella simplex Pasch. M) Pleurochloris pyrenoidosa Pasch. N) Botrydiopsis eriensis Snow. 


\subsection{Correlation between the soil physico-chemical parameters and the identified algal taxa}

The relation between the soil physicochemical parameters and the inhabiting algal divisions was assessed using Pearson's correlation coefficient in table (5) and illustrated using Biplot of Canonical Correspondence Analysis in fig (2). Concerning Chlorophyta, there was a markedly negative correlation $(r=-$ 0.901 at $p<0.01)$ with total sand and significant positive relationships with silt $(r$ $=0.900$ at $p<0.01)$ and clay content $(r=0.741$ at $p<0.05)$ of the soil. On the other hand, members of Xanthophyta showed significant positive relation $(r=$ 0.658 at $p<0.05)$ with total sand and significant negative relation with silt $(r=-$ 0.654 at $p<0.05)$ and clay content $(r=-0.633$ at $p<0.05)$ of their soil.

As regard to Xanthophyta, there was markedly significant negative relationship ( $r=-0.943$ and -0.858 at $p<0.01)$ between moisture content and organic matter of the soil and its inhabiting yellow-green algae (See table 5). In contrary, other algal divisions showed moderate significant positive effect especially members of Chlorophyta (Fig.2). Moreover, the results indicated the strong significant negative correlation $(r=-0.852,-0.882,-0.964$ and -0.838 respectively at $p<0.01$ ) between Xanthophyta and all available micronutrients $\mathrm{Fe}$, $\mathrm{Mn}, \mathrm{Cu}$ and $\mathrm{Zn}$. In general, there were also weak significant negative correlation between yellow-green algae and variable parameters including EC, TDS, cation $\left(\mathrm{Na}^{+}, \mathrm{K}^{+}, \mathrm{Ca}^{2+}, \mathrm{Mg}^{2+}\right)$, anions $\left(\mathrm{Cl}^{-}, \mathrm{SO}_{4}{ }^{2-}, \mathrm{HCO}_{3}{ }^{-}\right)$and nitrogen content.

On the other hand, Cyanophyta revealed strong significant negative correlation with all ionic contents of the soil particularly $\mathrm{Na}^{+}, \mathrm{Ca}^{2+}$ and $\mathrm{Mg}^{2+}(r=-$ $0.634,-0.637$ and -0.635 respectively at $p<0.05$ ) as well as EC and TDS (Fig. 2). Table (5) showed also that, $\mathrm{HCO}^{-}$content of the soil is negatively affecting all algal divisions under the study with markedly significant relation with Cyanophyta $(r=-0.940$ at $p<0.01)$ followed by Bacillariophyta algal taxa $(r=-$ 0.638 at $p<0.05)$. Results showed also strong significant positive correlation between nitrogen $(r=0.846$ at $p<0.01)$ for Bacillariophyta and moderate in Cyanophyta $(r=0.721$ at $p<0.05)$ and Chlorophyta $(r=0.673$ at $p<0.05)$. 
Table (5): Pearson's Correlation Coefficients $(r)$ between soil analysis of the selected sites and inhabiting algal divisions.

** Correlation is significant at the 0.01 level (1-tailed)

* Correlation is significant at the 0.05 level (1- tailed).

\begin{tabular}{ccccc}
\hline & Cyanophyta & Chlorophyta & Xanthophyta & Bacillariophyta \\
\hline $\begin{array}{c}\text { Total } \\
\text { Sand }\end{array}$ & -0.370 & $\mathbf{- 0 . 9 0 1 * *}$ & $\mathbf{0 . 6 5 8 *}$ & -0.518 \\
Silt & 0.370 & $\mathbf{0 . 9 0 0 * *}$ & $\mathbf{- 0 . 6 5 4}-*$ & 0.527 \\
Clay & 0.289 & $\mathbf{0 . 7 4 1 *}$ & $\mathbf{- 0 . 6 3 3 - *}$ & 0.187 \\
pH & 0.258 & 0.084 & 0.463 & 0.460 \\
EC & -0.630 & -0.388 & -0.583 & -0.186 \\
TDS & -0.630 & -0.388 & -0.583 & -0.186 \\
O.M. & 0.062 & 0.568 & $\mathbf{- 0 . 8 5 8 - * *}$ & 0.103 \\
M.C. & 0.050 & 0.560 & $\mathbf{- 0 . 9 4 3 - * *}$ & 0.294 \\
Na & $\mathbf{- 0 . 6 3 4 - *}$ & -0.408 & -0.565 & -0.194 \\
K & -0.603 & -0.270 & $\mathbf{- 0 . 7 4 3 - *}$ & -0.191 \\
Ca & $\mathbf{- 0 . 6 3 7 - *}$ & -0.375 & -0.628 & -0.208 \\
Mg & $\mathbf{- 0 . 6 3 5 - *}$ & -0.406 & -0.570 & -0.196 \\
Cl & -0.628 & -0.406 & -0.568 & -0.190 \\
SO4 & -0.622 & -0.366 & -0.616 & -0.183 \\
HCO3 & $\mathbf{- 0 . 9 4 0 - * *}$ & -0.626 & -0.432 & $\mathbf{- 0 . 6 3 8 - *}$ \\
N & $\mathbf{0 . 7 2 1 *}$ & $\mathbf{0 . 6 7 3 *}$ & -0.331 & $\mathbf{0 . 8 4 6 * *}$ \\
P & -0.234 & -0.463 & -0.083 & -0.418 \\
Fe & -0.092 & 0.457 & $\mathbf{- 0 . 8 5 2 - * *}$ & -0.083 \\
Mn & 0.010 & 0.505 & $\mathbf{- 0 . 8 8 2 - * *}$ & 0.072 \\
Zn & -0.270 & 0.208 & $\mathbf{- 0 . 9 6 4 - * *}$ & 0.013 \\
Cu & -0.187 & 0.141 & $\mathbf{- 0 . 8 3 9 - * *}$ & -0.072 \\
\hline
\end{tabular}




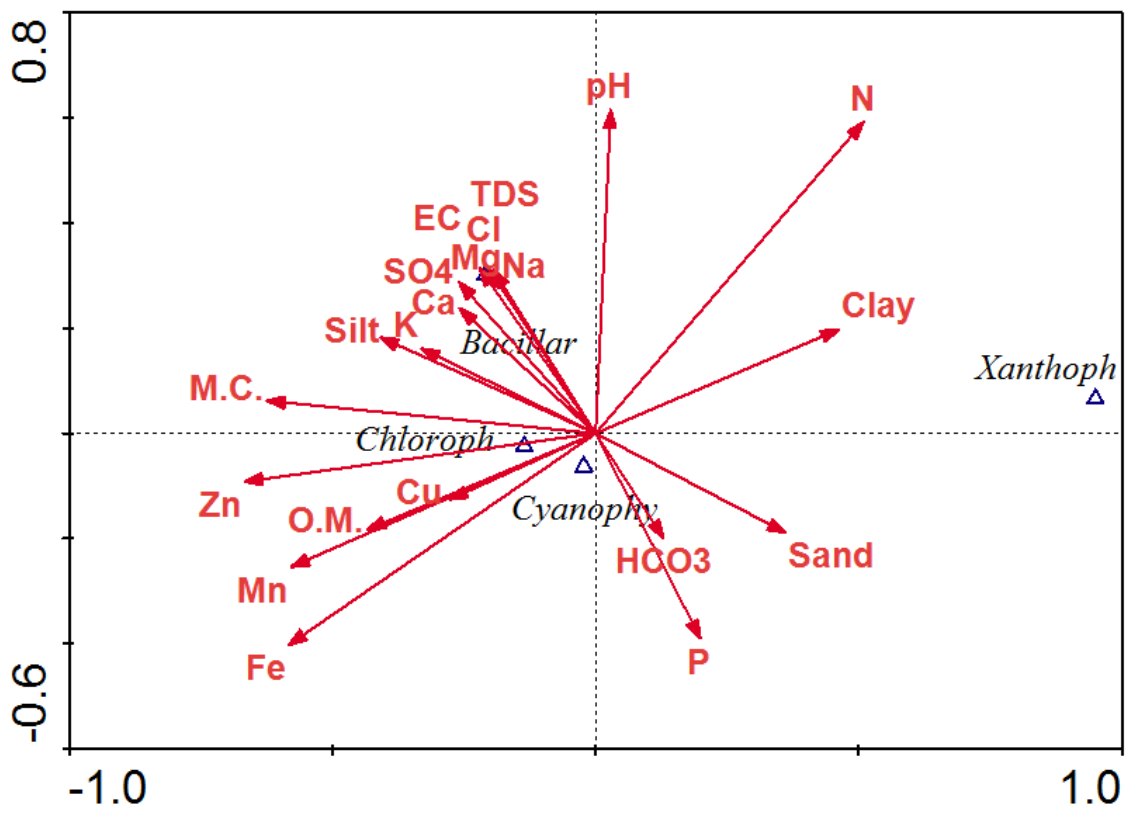

Figure (2): Biplot of Canonical Correspondence Analysis showing the relationships between the soil physicochemical parameters of localities under investigation and its inhabiting algal divisions.

\section{Discussion}

Despite of the generally known aquatic habitats of algae, they are also occupying different terrestrial habitats range from cold to hot environments as well as arid deserts. They occur either on the surface or down to several centimeters in the soil. Soil algae can survive a habitat with very low light intensities and low nutrients (Hoffmann, 1989). According to Bold and Wynne 
(1978), the algal flora of the soil includes mostly members of Cyanophyta, Chlorophyta, Euglenophyta, Bacillariophyta and Xanthophyta.

The current results clearly indicated that many of the studied soil physicochemical parameters varied between the studied soil localities. Previous studies of Shields and Durrell (1964), Macentee et al (1972) and Ibraheem and Al-Sherif (2009) reported also the association between the soil properties and their inhabiting algae.

One of the most parameters affecting algal distribution in the soil is the proportion of sand, silt and clay particles (soil texture) according to Starks et al (1981). In the present study, soil samples varied in their texture from site to another. The high percentage of sand particles confined to the soil of S2 and S4, while maximum ratio of silt and clay was associated with S3 and S5 soil. Our results showed a significant positive correlation between silt and clay soil structure and green algal members; however sandy soil exhibited a significant negative correlation. On the other hand, members of Xanthophyta showed significant positive relation with sand particles. In this respect, the present result indicates the role of silt and clay in selecting and distribution of green algae. According to de Cano et al (1997), fine particles such as silt and clay lead to more exposed surface in contrast to sandy soil which may result in the availability of more algae. However, results obtained by Fathi and Zaki (2003) indicated that the response of algal biomass at the different investigated sites to soil texture is not reflected in retarded or activated algal growth.

Also, soil $\mathrm{pH}$ is an important factor in determining the composition of algal communities. Our data revealed that, $\mathrm{pH}$ values of all soil samples under investigation were neutral to slightly alkaline. This may explain the greatest number of identified algal taxa from Cyanophyta over algal members of Chlorophyta and other groups. According to previous studies of Brock (1973), blue-green algae was completely absent at low $\mathrm{pH}$, whereas Chlorophyta and other eukaryotic algae flourish. It was confirmed later also by many studies (Salama and Kobbia, 1982; El-Gamal, 1995; El-Attar, 1999).Moreover, the high percentage of the cyanobacterial taxa in all investigated locations can be explained by the mechanisms employed by cyanobacterial cells to tolerate diverse conditions (Metting, 1981). Such assumption is in accordance with that of 
Kobbia and Shabana (1988), Ibraheem (2003) and Shaaban et al (2016) who explained the ability of blue-green algae to survive under variable conditions.

Although, it was no significant relation between $\mathrm{pH}$ and Cyanophyta, but this may be a result of non-significant differences indicated by the statistical analysis among the studied soil regions in $\mathrm{pH}$ values. In consistent, results observed by Zancan et al (2006) revealed that neutral conditions support the growth of most algal groups.

Results showed also higher algal populations of both S3 and S5 localities, especially cyanobacteria which may be attributed to the soil structure (high \% of silt and clay) of those sites. Another explanation, may be the relatively high nitrogen content of both sites which reflect their significant positive effect on the growth and multiplication of the soil algal flora as recorded before by Lund (1947) and Salama and Kobbia (1982).

Additionally, the presence of higher algal taxa in location S3 may be attributed to the nature of soil sample which located near cultivated land and so the possibility of the enrichment of the soil with $\mathrm{N}$ and $\mathrm{P}$ is present. Whereas, the reason for higher algal populations in site 5 could be due to relatively higher moisture content and organic matter of the soil. Both of them considered as a prime factor in abundance of algae in soils as described before by Al-Fredan and Fathi (2007) and El-Hameed et al (2007). Water availability is of primary importance in controlling life in terrestrial habitats in which water is present in the minute spaces between soil particles (Kennedy, 1993).

On the other hand, lower number of algal taxa in location S1 may be a result of the high salinity in this site even in the presence of high ratio of silt and clay. According to Handley (2003), one of the most factors that also affect algal diversity, the presence of Sodium chloride in relatively high concentrations in the soil. Our results revealed also, there was a significant negative correlation between sodium ion ratio and the number of algal taxa especially of blue green algae as observed before also by Alghanmi and Jawad (2019).

The green soil algal taxa of this study showed moderate positive relation with organic matter and moisture content. This was confirmed by the presence of Chlorella vulgaris, Chloroococcum humicola and Coelastrum microporum (green algae) in the location of S5 (Maximum values for O.M and M.C). Both algal 
species have predilection for organic matter and moisture content as essential factors for their growth. On the other hand, previous studies speculated that the organic nutrients might have a great effect on algae in terms of fertilization than inorganic nutrients(Ketchum, 1951).

It is also evident from results the presence of non-heterocytous cyanophytes Oscillatoria jasorvensisVouk, $O$. princeps Vaucher and $O$. terebriformis (Ag.) Elenk (bio-indicators of eutrophication) in site S3 and S5 might be linked to relative high content of available nitrogen (NowickaKrawczyk and Zelazna-Wieczorek, 2013; Mateo et al., 2015; Shaaban et al., 2015). In this connection, diatoms of certain soils grow only where appreciable amount of phosphorous and nitrates are available (Lund and John, 1945) which may explain the low percentage of this algal groups throughout the study. Finally, the presence of many heterocystous cyanophytes within the studied area particularly Nodularia harveyana f. sphaerocarpa (Born. et Flah.) Elenk can be recommended for the evaluation of atmospheric $\mathrm{N}_{2}$-fixation efficiency as mentioned before by Shaaban et al (2017).

Based on overall comparison of locations for many soil variables and algal populations revealed that, the soil texture, moisture content, bicarbonate, nitrogen and micronutrients are the most highly significant factors in controlling the diversity of soil algae at different locations. Finally, significant variation in soil properties throughout the studied locations as well as the correlations between edaphic algae and specific soil parameters was detected at this study.

\section{References}

Ahmed, Z. A. (1994). Preliminary survey of soil algal flora in Upper Egypt. Egyptian Journal of Botany (Egypt). 34(1), 17-36.

Al-Fredan, M. A., and Fathi, A. A. (2007). Preliminary survey of edaphic algae in al-hasa region, Saudi Arabia. Pakistanian Journal of Biological Science, 10(18), 3210-3214. 
Alam, M. A., Muhammad, G., Rehman, A., Russel, M., Shah, M., and Wang, Z. (2019). Standard Techniques and Methods for Isolating, Selecting and Monitoring the Growth of Microalgal Strain BT - Microalgae Biotechnology for Development of Biofuel and Wastewater Treatment (M. A. Alam and Z. Wang, eds.). https://doi.org/10.1007/978-981-13-22648_4

Alghanmi, H. A., and Jawad, H. M. (2019). Effect of Environmental Factors on Cyanobacteria Richness in Some Agricultural Soils. Geomicrobiology Journal, 36(1), 75-84.

Andersen, R. A. (2005). Algal culturing techniques. Elsevier.

Atia, Z. M. (1993). Ecological studies on the algal flora of Egyptian soils at Sohag district. MSc. Thesis „Bot. Dept. Fac. Sci.(Sohag), Assiut University, 152pp. un ....

Barsanti, L., and Gualtieri, P. (2014). Algae: anatomy, biochemistry, and biotechnology. CRC press.

Bharathiraja, B., Chakravarthy, M., Kumar, R. R., Yogendran, D., Yuvaraj, D., Jayamuthunagai, J., ... Palani, S. (2015). Aquatic biomass (algae) as a future feed stock for bio-refineries: a review on cultivation, processing and products. Renewable and Sustainable Energy Reviews, 47, $634-653$

Blank, G. B., and Cameron, R. E. (1966). Desert algae-Soil crusts and diaphanous substrata as algal habitats.

Bold, H. C, and Wynne, M. J. (1978). Introduction to the Algae Structure and Reproduction. Prentice-Ha11 1nc.

Bold, H. C. (1942). The cultivation of algae. The Botanical Review, 8(2), 69-138.

Brock, T. D. (1973). Lower $\mathrm{pH}$ limit for the existence of blue-green algae: evolutionary and ecological implications. Science, 179(4072), 480-483.

Büdel, B., Dulić, T., Darienko, T., Rybalka, N., and Friedl, T. (2016). Cyanobacteria and Algae of Biological Soil Crusts. In B. Weber, B. Büdel, and J. Belnap (Eds.), Biological Soil Crusts: An Organizing Principle in Drylands (pp. 55-80). https://doi.org/10.1007/978-3-31930214-0_4 
Cantonati, M., Rott, E., and Pipp, E. (1996). Ecology of cyanophytes in mountain springs of the river Sarca catchment (Adamello-Brenta Regional Park, Trentino, Northern Italy). Algological Studies/Archiv Für Hydrobiologie, Supplement Volumes, 145-162.

Chu, S. P. (1942). The influence of the mineral composition of the medium on the growth of planktonic algae: part I. Methods and culture media. The Journal of Ecology, 284-325.

Colsell, A. (2020). Cultivation, isolation and characterisation of thermophilic and acidophilic red algae, Cyanidiales. a thesis submitted in partial fulfilment of the requirements for the degree of Master's in Science in Biotechnology at the University of Canterbury.

Curl, H., and Becker, P. (1970). Terrestrial cryophilic algae of Antarctic Peninsula. Antarctic Journal of the United States, 5(4), 121.

de Cano, M. S., de Mulé, M. C. Z., de Caire, G. Z., Palma, R. M., and Colombo, K. (1997). Aggregation of soil particles by Nostoc muscorum Ag.(Cyanobacteria). Phyton. 60:33-38

De Desenko-Schegolova, N. T. and Gollerbach, M. M. (1962) "Freshwater Algae of USSR". Vol. 5. Xanthophyta. Pub. Acad." Sov. Nauke" USSR, Moscow, Leningrad.

Desikachary, T. V. (1959). Cyanophyta (Vol. 2). Indian Council of Agricultural Research New Delhi.

Dos Santos, A. L., Gourvil, P., Tragin, M., Noël, M.-H., Decelle, J., Romac, S., and Vaulot, D. (2017). Diversity and oceanic distribution of prasinophytes clade VII, the dominant group of green algae in oceanic waters. The ISME Journal, 11(2), 512-528.

El-Attar, S. A. (1999). Studies on the soil algal flora at Qalyoubia Province Egypt. Egyptian Journal of Botany (Egypt). 39: 127-145.

El-Ayouty, E. Y., and Ayyad, M. A. (1972). Studies on blue-green algae of the Nile Delta, 1-Description of some species in a wheat field. Egyptian Journal of Botany, 15(2), 283-321. 
El-Gamal, A D. (1995). Systematical studies on the algae isolated from some cultivated areas and laboratory studies on the effect of light, temperature and humidity on three selected soil algae. Ph. D. Thesis, Fac. of Sci., AlAzhar University, Cairo, Egypt.

El-Gamal, Ahmed D, Ghanem, N. A. E., El-Ayouty, E. Y., and Shehata, E. F. (2008). Studies on soil algal flora in Kafr El-Sheikh governorate, Egypt. Egyptian Journal of Phycology. Vol, 9 (2), 1-23.

El-Hameed, A., Hamouda, O., Kobbia, I., and Hassan, S. (2007). Correlation between algal taxa and physicochemical characters of the protected area of Wadi El-Rayan, Egypt. International Journal of Agriculture and Biology, 91, 1-10.

El-Sheekh, M. M., El-Beheiry, M. A., and El-Kady, H. F. (1998). 13 Soil algae of Thymelaea hirsuta and Asphodelus microcarpus in mediterranean desert of Egypt. Egyptian Journal of Botany, 38(1-2), 185-204.

El-Sheekh, M. M., Deyab, M. A. I., Desouki, S. S., and Eladl, M. (2010). Phytoplankton compositions as a response of water quality in El Salam canal, Hadous drain and Damietta branch of River Nile, Egypt. Pakistanian Journal of Botany. 42(4), 2621-2633.

Fathi, A. A., and Zaki, F. T. (2003). Preliminary survey of edaphic algae in ElMinia region, Nile Valley, Egypt. Egyptian Journal of Phycology 4(2), 131-148.

Foged, N. (1980). Diatoms in Egypt. CramerBraunschweig. Nova Hedwigia 33 629-707

Gaysina, L. A., Eliaš, M., and Gontcharov, A. A. (2018). Biodiversity of algae and cyanobacteria in volcanic soils near Mutnovsky and Gorely volcanoes (Kamchatka peninsula). The 1st International Conference on North East Asia Biodiversity. Vladivostok, 137-139.

Gupta, S., and Agrawal, S. C. (2006). Survival of blue-green and green algae under stress conditions. Folia Microbiologica, 51(2), 121-128.

Handley, M. A. (2003). The distribution pattern of algal flora in saline lakes in Kambalda and Esperance, Western Australia. Curtin University. 
Hodac, L. (2016). Green algae in soil: assessing their biodiversity and biogeography with molecular-phylogenetic methods based on cultures. Niedersächsische Staats-und Universitätsbibliothek Göttingen.

Hoffmann, L. (1989). Algae of terrestrial habitats. The Botanical Review, 55(2), 77-105.

Ibraheem, I. B. M., and Al-Sherif, E. A. (2009). Distribution of flowering plants and cyanobacteria in relation to soil characters in Bahariya Oasis, Egypt. International Journal of Botany, 5(1), 36-46.

Ibraheem, I. B. M. (2003). Preliminary survey of microalgal soil crusts in a xeric habitats (Wadi-Araba, Eastern desert, Egypt). Egyptian Journal of Phycology, 4 (1), 19-35.

Jurgensen, M. F., and Davey, C. B. (1968). Nitrogen-fixing blue-green algae in acid forest and nursery soils. Canadian Journal of Microbiology, 14(11), 1179-1183.

Kennedy, A. D. (1993). Water as a limiting factor in the Antarctic terrestrial environment: a biogeographical synthesis. Arctic and Alpine Research, 25(4), 308-315.

Ketchum, B. H. (1951). Plankton algae and their biological significance. Smith, GM Manual of Phycology, 335-346.

Khairy, H. M., and El-Shafay, S. M. (2013). Seasonal variations in the biochemical composition of some common seaweed species from the coast of Abu Qir Bay, Alexandria, Egypt. Oceanologia, 55(2), 435-452.

Kobbia, I. A., and Shabana, E. F. (1988). Studies on the soil algal flora of Egyptian Bahariya Oasis. Egyptian Journal of Botany, 31, 1-3.

Lund, J. W. G. (1947). Observations on soil algae II. Notes on groups other than diatoms. The New Phytologist, 46(1), 35-60.

Lund, John W. G. (1945). Observations on soil algae: I. The ecology, size and taxonomy of British soil diatoms. New Phytologist, 44(2), 196.

Macentee, F. J., Schreckenberg, S. G., and Bold, H. C. (1972). Some observations on the distribution of edaphic algae. Soil Science, 114(3), 171-179. 
Mansour, H. A. (2008). Natural and propagated algal flora isolated from ElFayum Governorate. Egyptian Journal of Biology, 10(1), 54-61.

Mansour, H A, and Shaaban, A. S. (2010). Algae of soil surface layer of Wadi Al-Hitan protective area (world heritage site), El-Fayum Depression, Egypt. Journal of American Science, 6(8), 243-255.

Mansour, H. A., Hamed, A. F., and Nosair, H. R. (2020). Morphological and molecular taxonomic studies of edaphic cyanobacteria from Siwa Oasis, Egypt. The Egyptian Journal of Experimental Biology (Botany), 16(2), 149-160.

Mateo, P., Leganés, F., Perona, E., Loza, V., and Fernández-Piñas, F. (2015). Cyanobacteria as bioindicators and bioreporters of environmental analysis in aquatic ecosystems. Biodiversity and Conservation, 24(4), 909-948.

Metting, B. (1981). The systematics and ecology of soil algae. The Botanical Review, 47(2), 195-312.

Nayaka, S., Toppo, K., and Verma, S. (2017). Adaptation in Algae to Environmental Stress and Ecological Conditions. In Plant Adaptation Strategies in Changing Environment (pp. 103-115). Springer.

Novakovskaya, I. V, Dubrovskiy, Y. A., Patova, E. N., Novakovskiy, A. B., and Sterlyagova, I. N. (2020). Influence of ecological factors on soil algae in different types of mountain tundra and sparse forests in the Northern Urals. Phycologia, 59(4), 320-329.

Nowicka-Krawczyk, P. B., and Zelazna-Wieczorek, J. (2013). Cyanobacteria microflora in a limestone spring (Troniny spring, Central Poland). Acta Societatis Botanicorum Poloniae, 82(3).

Osman, M. E. H., El-Naggar, A., Omar, H. H., and Esmail, G. H. (2003). Distribution of different soil algal taxa in relation to physico-chemical characteristics of soil at Gharbia governorate. Egyptian Journal of Phycology. 4 (1), 37-54.

Page, A. L., Miller, R. H., and Keeney, D. R. (1982). Methods of soil analysis. Part 2. American Society of Agronomy. Soil Science Society of America, Madison, WI, USA. 
Page, A. L., Miller, R. H., Keeney, D. R., Baker, D. E., Ellis, R., and Rhoades, J. D. (1982). Methods of soil analysis. eds.

Prescott, G. W. (1978). How to know the freshwater algae. Wm. C. $C$ Brown Company Publishers, UK.

Provasoli, L. (1960). Artificial media for fresh water algae: problems and suggestions. The Ecology of Algae, 2, 84-96.

Roger, P.-A., and Reynaud, P.-A. (1982). Free-Living blue-Green algae in tropical soils. In Microbiology of tropical soils and plant productivity (pp. 147-168). Springer.

Salama, A. M., and Kobbia, I. A. (1982). Studies on the algal flora of Egyptian soils. II Different sites of a sector in the Libyan desert. Egyptian Journal of Botany, 25, 139-158.

Schinner, F., Öhlinger, R., Kandeler, E., and Margesin, R. (2012). Methods in soil biology. Springer Science and Business Media.

Shaaban, A. E.-S. M., Hamed, A. F., and Mansour, H. A. (2016). Algal Flora of Egyptian Soils 1. The occurrence of Cyanobacteria and Algae in some habitats. Taeckholmia, 20(2).

Shaaban, A. E.-S. M., Mansour, H. A., and Saber, A. A. (2015). Unveiling algal biodiversity of El-Farafra Oasis (Western Desert, Egypt) and potential relevance of its use in water bio-assessment: special interest on springs and drilled wells. Egyptian Journal of Phycology. 16(47), 47-74.

Shaaban, A. E.-S. M., Mansour, H., and Saber, A. A. (2017). Soil Algae of ElFarafra Oasis (The Western Desert, Egypt) and N2-fixation Efficiency of Five Heterocytous Cyanophytes. Egyptian Journal of Botany, 57(3), 517524.

Shaaban, A. S. (1994). Freshwater algae of Egypt. UN Environmental Programme.

Shields, L. M., and Durrell, L. W. (1964). Algae in relation to soil fertility. The Botanical Review, 30(1): 92-128. https://doi.org/10.1007/BF02858614

Singh, P., Gupta, S. K., Guldhe, A., Rawat, I., and Bux, F. (2015). Microalgae isolation and basic culturing techniques. In Handbook of marine microalgae (pp. 43-54). Elsevier. 
Smith, R. L., and Wiedeman, V. E. (1964). A new alkaline growth medium for algae. Canadian Journal of Botany, 42(11), 1582-1586.

Snedecor and Waddel. (2008). In The Concise Encyclopedia of Statistics. https://doi.org/10.1007/978-0-387-32833-1_376

Starks, T. L., Shubert, L. E., and Trainor, F. R. (1981). PHYCOLOGICAL REVIEWS 6 Ecology of soil algae : a review. 20, 65-80.

Sullivan, M. J., and Moncreiff, C. A. (1988). Primary production of edaphic algal communities in a Mississippi salt marsh. Journal of Phycology, 24(1), 49-58.

Sylvia, D. M., Fuhrmann, J. J., Hartel, P. G., and Zuberer, D. A. (2005). Principles and applications of soil microbiology. Pearson Prentice Hall Upper Saddle River, NJ:

Temraleeva, A. D., Dronova, S. A., Moskalenko, S. V, and Didovich, S. V. (2016). Modern methods for isolation, purification, and cultivation of soil cyanobacteria. Microbiology, 85(4), 389-399.

Trainor, F. R. (1985). Survival of algae in a desiccated soil: a 25 year study. Phycologia, 24(1), 79-82. https://doi.org/10.2216/i0031-8884-24-1-79.1

van Elsas, J. D. (2019). 1 The Soil Environment. Modern Soil Microbiology, 1.

Vijayan, D., and Ray, J. G. (2015). Green algae of a unique tropical wetland, Kuttanadu, Kerala, India, in relation to soil regions, seasons, and paddy growth stages. International Journal of Science, Environment and Technology, 4(3), 770-803.

Walkely, A., and Black, I. A. (1934). An examination of the Degtjareff method for determination of soil organic matter and a proposal modification of the chronic acid titration method.

Zancan, S., Trevisan, R., and Paoletti, M. G. (2006). Soil algae composition under different agro-ecosystems in North-Eastern Italy. Agriculture, Ecosystems and Environment, 112(1), 1-12. 


\title{
صفات التربة الفيزيائية والكيميائية وعلاقتها بالمحتوى الطحلبي لها
}

\author{
عبد السلام محمد شعبان ، هدى أنور منصور * ، نعمات حسن الطبلاوي \\ قسم النبات ـ كلية العلوم - جامعة عين شمس
}

تم تجميع خمس عينات من التربة (1-5) من مناطق مختلفة في مصر لدراسة نأثير العوامل

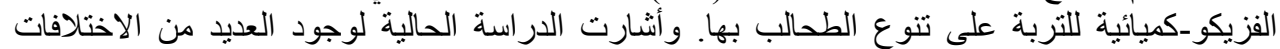

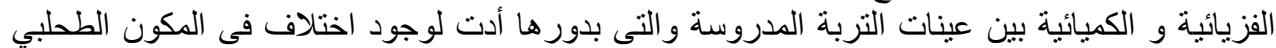

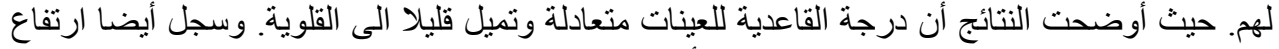

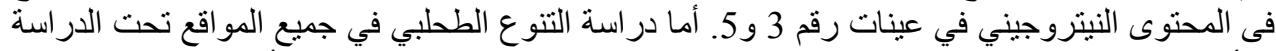

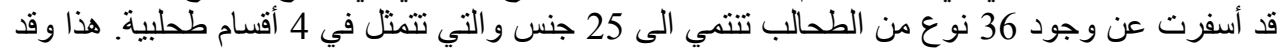

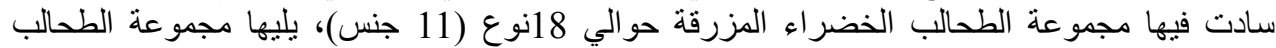

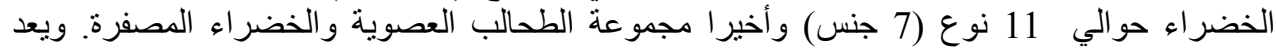

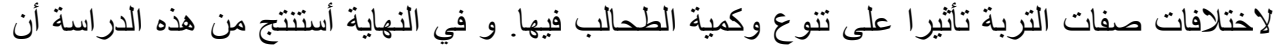

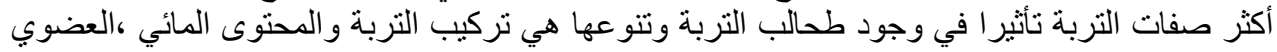

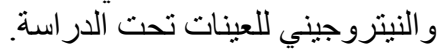

